(D) Meral Melekoğlu ${ }^{1}$

(D) Aydin $\mathrm{Bal}^{2}$

(D) İbrahim H. Diken ${ }^{3}$

\title{
Implementing School-Wide Positive Behavior Interventions and Supports (SWPBIS) for Early Identification and Prevention of Problem Behaviors in Turkey
}

Abstract

Early childhood education is critical as children learn essential motor, cognitive, and social skills. Positive behavior interventions and supports is an evidence-based, proactive multitier systems of support to prevent and adress behavioral problems in schools. The purpose of this article is to explore the implementation of SWPBIS in early childhood education in Turkey and provides guidelines regarding its effective and culturally responsive adaptation in Turkish schools. The authors sought to answer the following questions: What is SWPBIS? What are the key features of early childhood education system and settings in Turkey? and What are the key considerations and steps to implement SWPBIS for early childhood education in Turkey?

Keywords: School-wide positive behavior interventions and supports, early identification and prevention, problem behaviors

\section{Introduction}

Early childhood education is defined as the education of children from birth to eight years old (The United Nations Children's Fund [UNICEF], 2001). In terms of human development, this period is critically important because children acquire essential motor, cognitive, and social skills. Caregivers, educators, and child specialists should monitor children's' development to provide rich learning opportunities and scaffold children's' skills in a safe and positive environment. If developmental delays are observed, various support and intervention strategies should be implemented as early and developmentally and socially appropriate as possible.

The term developmental delay is defined as a delay in one or more of the following areas: Physical, cognitive, communication, social/emotional or adaptive behavioral development (The Individuals with Disabilities Education Act [IDEA], 2004). Developmental delays in intellectual, motor, speech, and language areas may be observed relatively easily in early ages. However, the identification of social/emotional delays is more complicated. Literature shows that there is a significant need for effective and appropriate early identification and intervention models in order

\footnotetext{
${ }^{1}$ Ph.D., Lecturer. Eskişehir Osmangazi University, Department of Special Education, Eskişehir, TURKEY, e-mail: meralmelekoglu@gmail.com

${ }^{2}$ Ph. D., Associate Prof., University of Wisconsin-Madison, Department of Rehabilitation Psychology and Special Education, Wisconsin-Madison, U.S. e-mail: abal@wisc.edu

${ }^{3}$ Ph.D., Prof., Anadolu University, Research Institute for Individuals with Disabilities, Eskişehir, TURKEY. e-mail: ibrahimhalildiken@gmail.com
} 
to prevent and manage problem behaviors (Anderson, 2007; Bullis, Walker, \& Sprague, 2001; United Nations Educational, Scientific and Cultural Organization [UNESCO], 2005). Since 1990s, schoolwide positive behavior interventions and supports (SWPBIS) has become the primary means of providing behavior support and prevention in schools. Indeed, PBIS is the only school-wide identification and early intervention model for behavioral problems specifically mentioned in IDEA (2004). PBIS has been implemented in more than $20 \%$ of all schools in the United States (U.S.; Horner, 2015). PBIS has been increasingly used in education systems around the world including but not limited to Australia, Canada, Norway, Japan, and Taiwan.

The purpose of this study is to discuss the implementation of SWPBIS in early childhood education in Turkey. We sought to answer the following questions:

1. What is SWPBIS?

2. What are the key features of early childhood education system and settings in Turkey?

3. What are the key considerations and steps to implement SWPBIS for early childhood education in Turkey?

In what follows, we first review the identification and prevention of behavior problems in early childhood in Turkey. Then, we review the key features of SWPBIS and its implications for early childhood education. Finally, we present the implementation of SWPBIS in the context of the Turkish early childhood education system.

\section{Identification and Prevention of Behavioral Problems in Early Childhood in Turkey}

Caregivers and early childhood teachers are usually the first to recognize problem behaviors and social/emotional delays in children. A child is often referred to a specialist (e.g., pediatrician). Specialists may diagnose children with problem behaviors based on Diagnostic and Statistical Manual of Mental Disorders (DSM-V; 2013). After a child receive a diagnosis, the Guidance and Research Centers (GRC) are responsible for assessing the development of the child in terms of that child's education needs and to place the child in inclusive classrooms with the requirements of the Individual Edu- cation Plan (IEP; Republic of Turkey Ministry of National Education, 2012a). GRC conducts educational assessments to identify child's general educational goals and prepare an IEP.

Once the child is diagnosed with a disability goes to schools in general education classrooms or early childhood special education classrooms based on GRC's report. Early childhood teachers and the IEP team oversee child's IEP goals. The IEP team conduct evaluations in order to achieve the child's education goals. For children between 0-8 years old who are at risk an emotional behavioral disorder (EBD) GRC supports parents about how to manage problem behaviors (Er-Sabuncuoğlu \& Diken, 2010).

\section{Prevention Approaches of Problem Behav- iors}

Numbers of children experiencing problem behaviors have been increasing since 1990s (Diken \& Rutherford, 2005; Melekoğlu et al., 2014; Safran \& Oswald, 2003; Sprague \& Perkins, 2009). This has pressured researchers, educators, specialists and policy makers to seek for evidencebased, socially and developmentally appropriate, and sustainable interventions to prevent the problem behaviors in schools. It has been recommended that the interventions should create positive, supportive, predictable school climate for all students as well as adults (The Office of Special Education Programs, 2010; Walker et al. 1998). Moreover, the interventions should include reliable assessments for progressmonitoring. The other features of effective interventions include schoolwide expectations and reinforcement system and involving all stakeholders (e.g., education leaders, parents, teachers and students) in problem solving and decision-making activities (Bal, 2016). In fact, collaboration and collective agency among local stakeholders are identified as the key components of culturally responsive systemic interventions (Bal, 2011). Fox, Dunlap and Lisa (2002) stressed the importance of family involvement in the effective early intervention programs. Professionals should to take into account family strengths, goals, social context, histories, and cultural practices and establish sustained and reciprocal collaboration in the development and implementation of the behavioral interventions. In the litera- 
ture, there are evidence-based early intervention programs such as First Step to Success (Walker et. al., 1998), Head Start's Early Family Support Program (BulotskyShearer et al., 2010).

Sugai and Horner (2006) concisely summed up that "[t]he SWPBIS approach is about redesigning learning and teaching environments so that the best and most appropriate evidence-based practices can be adopted and implemented at the classroom and schoolwide levels" (p. 256). SWPBIS has been found to decrease office discipline referrals in elementary schools (Horner et al., 2009). The evidence-based practices were used in the prevention of problem behaviors include establishing a family outreach program, improving academic skills of children, creating individual behavior support programs, providing intellectual behavioral supports and teaching and modeling social skills (Blackbourn et al., 2004; Lewis \& Sugai, 1999). Below we present the key tenets of SWPBIS.

\section{Positive Behavior Intervention and Sup- ports}

PBIS was grounded in applied behaviorism and followed the method of applied behavior analysis (ABA; Baer, Wolf, \& Risley, 1968; Sugai \& Horner, 2002b). PBIS is a framework consisted built on over three studies of ABA and tiered, prevention models from public health (Carr, 1997; Carr et al., 2002). Since the 1990s, researcher have emphasized the effectiveness of PBIS strategies in order to prevent problem behaviors (Lewis \& Sugai, 1999). PBIS emerged as an alternative approach to traditional discipline and behavioral management practices (e.g., punishment). Most commonly, adults in schools and at home often focus on children's negative or undesired behaviors (e.g., yelling, hitting, disobeying, tantrum, biting) rather than teaching, modeling, and reinforcing positive behaviors. Positive behaviors often go without acknowledgement, praise, or reward. PBIS considers the whole school context and opportunities for positive behaviors, social values, and happiness of children. SWPBIS aims to teach, model, and reward children's desired behaviors (Carr et al., 2002).

The 1997 reauthorization of the IDEA recommended SWPBIS. It was suggested that each school's disciplinary regulations and behavior management programs should include "positive behavioral interventions and supports" strategies and approaches. With this federal law, "functional assessment" and "positive behavior support" become central considerations in school-wide interventions to address behavioral problems.

The earlier studies on PBIS generally included the applications at the individual level (e.g., Clarke et al., 2002) or class-wide (e.g., Lohrmann, \& Talerico, 2004). Since 2000s, school-, district-, and state-wide implementations of PBIS have been the most prominent forms (Barrett, Bradshaw, \& Lewis-Palmer, 2008). In recent years, PBIS applications took into account culture given the fact that SWPBIS has mostly worked for the students from dominant cultural groups. SWPBIS has not been able impact the racial disparities in behavioral outcomes (e.g., ODRs, suspension, and placement in special education for EBD; Bal, Sullivan, \& Harper, 2014; Sugai et. al., 2000).

\section{Key Features of SWPBIS}

Kincaid and colleagues (2016), conducted a study with members of the Association for Positive Behavior Support (APBS) in order to reach an encompassing definition of PBIS. The APBS members defined SWPBIS as "an approach to behavior support that includes an ongoing process of research-based assessment, intervention and data-based decision making focused on building social and other functional competencies, creating supportive contexts, and preventing the occurrence of problem behaviors" (Kincaid et al., 2016, p. 71). This study and the larger literature indicate that a SWPBIS implementation should have the following key features:

- SWPBIS should be implemented as school wide

- School staff should have buy-in

- A SWPBIS team should lead and monitor the implementation

- All stakeholders' involvement should be maintained

- SWPBIS team' first priority should be prevention the problem behaviors

- A continuum of behavior support system should be created

- Evidence-based practices should be used

- A strong school management system should be built 
- Fidelity of implementation should be monitored

- SWPBIS team should make databased decisions

- Contextual fitness or culturally responsiveness should be established

- Providing a good quality of life cycle for the children

In the following section, we discuss the implementation of SWPBIS for early childhood education.

\section{Implementation SWPBIS in Early Childhood}

Effectively addressing problem behaviors in schools are notably complex and difficult. Traditionally, teachers try to cope with children with problem behaviors by using intervention strategies targeting individual students. However, the literature showed that the effective behavioral interventions should focus on the whole school context and adult behaviors as well as individual student behaviors (Lewis \& Sugai, 1999; Stormont, Lewis, \& Convington Smith, 2005). Sugai and Horner (2002a) indicated four key features of PBIS: "1) Outcomes, 2) a behavioral and biomedical science of human behavior, 3) empirically validated practices for achieving identified outcomes in applied contexts, and 4) the implementation of validated practices in the context of the systems change" (p. 29). Data, system and practices are strategically established for improved and sustained desired behavioral outcomes. In other words, there is a helical relationship between these elements. These factors also consider professional development of school staff, positive attitude of the students, data-based decision making system the social values of schools, social skills and academic achievement students.

School-wide interventions generate solution offers with cooperation of administrators, parents, educators, and behavioral specialists (e.g., school psychologists, social workers; Sugai \& Horner, 2002b; Sugai \& Horner, 2006). The commitment and leadership of school administration and the active involvement of the whole school community are important components to establish a schoolwide system of behavioral prevention and interventions. The aim of the SWPBIS is to examine structure of schools in general (staff, environment, family, students and administration), determine schoolwide behavioral expectations (e.g., be respectful, be safe, and be responsible), operationalize those desired behaviors in various school spaces and activities (e.g., classroom, cafeteria, school bus, playground, and restrooms), teach, model, and reinforce positive behaviors. SWPBIS teams also develop a plan for identifying and addressing problem behaviors (e.g., consequences) and examine factors causing behavior problems (Anderson, 2007).

Quality of teamwork and leadership were found critical in SWPBIS implementations (Sugai \& Horner, 2002b; 2005; Steed \& Webb, 2012; Stormont, Lewis, Beckner, \& Johnson, 2008). Additionally, accountability, material and administrative support, the training of the team, and cooperation between all stakeholders were found effective (Flannery, Sugai, \& Anderson, 2009; Sugai \& Horner, 2006).

\section{Implementation steps of PBIS}

SWPBIS is not a pre-packed program and its implementation may vary from school to school depending on each school communities' needs, goals, and resources (Horner \& Sugai, 2000). In the SWPBIS implementation, a school community may follow steps: Forming a SWPBIS team, clearly defining responsibilities of team members, collecting data for the fidelity of implementation, and collecting follow up data. Horner and Sugai (2000) elaborated the steps that a SWPBIS team may take:

- Planning implementation process by the school team

- Managing and supporting SWPBIS implementation

- Determining and operationally defining three to five specific values based on behavioral expectations (e.g., be honest, be respectful, and share)

- Teaching the behavioral expectations to all students in a tangible and systematic way,

- Giving feedback and rewarding systematically the children meeting behavioral expectations

- Applying positive behavior support strategies such as teaching new skills to prevent the problem behaviors 
- Monitoring scientifically progress of students' behaviors

In general, SWPBIS has been implemented in a three-tiered continuum (Lewis \& Sugai, 1999; Sugai \& Horner 2002b; 2006; Walker et al., 1996).

Primary Prevention Level. This level is also called universal tier in which the intervention program targets all students and adults in the school. The PBIS team members collectively determine schoolwide desired behaviors (Sugai \& Horner, 2002b). In this process, the team should seek active participation of parents and community members. It aims at preventing problem behaviors and bringing all students in desired academic, social, behavioral or prerequisite skills in the school by providing positive reinforcement for appropriate behaviors and establishing positive learning environment for all (Sugai \& Horner, 2006). The intervention program also contains basic support strategies such as teaching appropriate behaviors, giving feedback, treating to children in positive way (Horner \& Sugai, 2006; Stormont, Lewis, \& Beckner, 2005; Stormont et al., 2008). It is assumed that about $80-85 \%$ of students may respond to interventions at this level (Stormont, Lewis, \& Beckner, 2005; Stormont et al., 2008).

Secondary Prevention Level. The secondary tier behavioral support services target students who may benefit from additional, more intensive, in small group support programs to develop appropriate social skills, self-management strategies, and academic skills to cope with problem behaviors before they become permanent. The SWPBIS scholars suggested that approximately $10-15 \%$ of students in the schools may benefit from this level of support. Teachers or researchers can utilize FBA. Secondary interventions contain more intensive adult attention and monitoring child with problem behaviors (Sugai \& Horner, 2006).

Tertiary Prevention Level. Students in this group who do not respond to universal and more intensive, small group behavioral interventions mainly need for individual behavior intervention and supports. These students show intense problem behaviors even after the universal and targeted group intervention strategies (Horner \& Sugai, 2006; Stormont, Lewis, \& Beckner, 2005; Stormont et al., 2008). At this level, intervention strategies are built based on a com- prehensive Functional Behavioral Assessments (FBA), which informs teachers or researchers about nature of problem behaviors that a student experiences. In Turkey, especially teachers struggle with creating individual behavior intervention and supports intervention plan because of the lack knowledge about effective strategies and special education and specialists such as special education teacher, school guidance counselor, and averseness of parents, crowed classroom size. For tertiary prevention, collaboration between stakeholders is vital in order to successfully implement individualized behavioral interventions and if needed start the special education referral (Algozzine, Daunic, \& Smith, 2010).

The literature does not differentiate the steps for SWPBIS implementations for in early childhood education settings. Fox and Little (2001) conducted a study on PBIS in an early childhood education setting and listed the implementation process in seven steps: Determining and defining behavioral expectations, teaching expected behaviors, giving feedback for kids' appropriate behaviors, conducting prevention strategies, building a team program to make evaluation, supporting school leaders, conducting an individual behavior support plan for a child who shows severe problem behaviors. Steed \& Webb (2012) developed the Preschool-Wide Evaluation Tool (Preset) to assess the reliability of SWPBIS applications. Based on this assessment tool implementation steps of SWPBIS must contain below essential features.

1. Determining three to five behavioral expectations based on children needs

2. Teaching target behaviors to children

3. Giving the feedback on children's behavior

4. Creating positive learning environment

5. Progress monitoring students' behaviors

6. Making data-based decision

7. Participating families in practices

8. Providing a fair and democratic staff management

9. Building a strong and effective behavior management system

10. School administration's support 


\section{Culturally responsive SWPBIS}

School culture, social contexts and the readiness and needs of schools impact the implementation of SWPBIS (Horner \& Sugai, 2000; Sugai at al., 2000). Therefore, contextually fit or culturally responsive implementations of SWPBIS were recommended in the literature (Bal, 2011; Bal, 2016; Sugai, O'Keeffe, \& Fallon, 2012). SWPBIS implementers can utilize funds of knowledge (cultural practices, histories) that students and families bring to schools (Moll, Amanti, Neff, \& Gonzàles, 1992).

Bal (2011) developed a culturally responsive PBIS (CRPBIS) framework which offers Learning $L a b$, an inclusive problem solving process to address outcome disparities in school discipline. Learning Lab facilitates active participations of parents, students, and community members in schools' decision making activities to collectively design culturally responsive school discipline systems. In a statewide, mixed methods research study, Learning Labs were implemented at five urban preK-12 schools in U.S. The Learning Lab methodology was found to successfully facilitate and sustain reciprocal and productive partnerships among local stakeholders that renovated their schoolwide behavioral support systems to be positive, inclusive and culturally responsive (Bal, 2016; Bal et al., 2014).

\section{Implementing PBIS in Turkey in early child- hood education}

Turkey has a centralized education system with a national curriculum. Formal early childhood education begins at age 3 in early childhood schools (Ministry Education of Turkey, 2014). There are private early childhood schools for children younger than 3 years old. Early childhood education is not for free. There are three types of early childhood institutions in Turkey: (a) Pre-school: Provides education to children who are between 36-66 months old; (b) kindergarten: Provides education mostly in the primary schools to children who are between 48-66 months old; (c) Training class: Provides education to children 36-66 months in vocational and technical education school as a part of child development and education field (Ministry of National Education, 2014).

Early childhood schools provide dual education system to one group of children from 7:30 a.m. to $12: 45$ p.m. and other group of children from 1: 45 p. m. to 5:45 p.m. (Ministry of National Education, Early
Childhood and Primary Education Institutions Regulation, 2014). There are usually early childhood education teachers, a principle, one or two vice-principle, administrative assistants, teacher assistant if hired by parents, and a guidance counselor in independent early childhood education settings (Melekoğlu, 2017). There are usually total six to fourteen classrooms in independent early childhood schools and four to six kindergarten classrooms in elementary or middle schools. Maximum 25 children can be enrolled in one class with one teacher. The regulation also requests that only 20 children can be enrolled if there is a child with disability in one class with one teacher. If there are two children with disabilities, only ten children can be enrolled in one class with one teacher.

There is officially one teacher in the classroom but parents may hire an assistant teacher. Classroom size does not differ based on the age group. In fact, Melekoğlu, (2017) found that 25 children might be too challenging for one teacher in terms of children safety and quality of education. In practice, however, school administration sometimes does not follow those rules. For instance, there may be students more than 25 students (Melekoğlu, 2017). Also, there may be more students with disabilities more than the suggested in the law but school administration cannot decrease the classroom size due to lack of available classrooms and teachers. As a result, school administration and teachers struggle with adequately addressing problem behaviors because of classroom size as well as other structural problems in schools (Melekoğlu, 2017).

Early childhood teachers are often left alone without any structured, systemic support and guidance to address behavioral problems as well as other educational challenges such as the inclusion of students with disabilities, lack of education materials and professional learning opportunities, and the issues related to classroom management (Er-Sabuncuoğlu \& Diken, 2010). On the other hand, there are only a few research-based intervention strategies to deal with behavioral problems (Diken et. al., 2010). The exiting interventions are mostly about inclusive education in early childhood education yet they are rarely used in schools (Sucuoğlu \& Bakkaloğlu, 2013). As a research-based, systemic intervention model, SWPBIS can be an effective way to address behavioral problems and increase positive, proactive, and supportive social 
climate in early childhood education settings in Turkey.

There have been system-wide intervention programs. For example, the Project of Inclusive/Integration Education Support Model was developed by a partnership between Ministry of National Education, Tohum Otizm Vakfı, Sabanci University, and Education Reform Union in 2011. The aim of the project was to provide quality inclusive education to students with disabilities. The second project was the Inclusive Education in Early Childhood-Evaluation Outcomes of Teacher Training program in 2011 (Sucuoğlu \& Bakkaloğlu, 2013). In early childhood education, the first program, especially applied for preventing and dealing with problem behaviors, was First Step to Success (FSS; Diken et al., 2010).

Recently, with a direction from Ministry of National Education (2010), schools are implementing value education, also known as character education, in daily activities for the request of Early Childhood and Primary Education Institutions Regulation (part 1, item 5,7; 2012b) and (part 8, item 52; 2014b). The goal is to gain children prosocial skills and "good personality" (Cihan, 2014; Ministry of National Education, 2010). In this program, the Ministry pre-determines "values" and "desired behaviors" to teach to the children and declare them to schools. These values are usually chosen from the regulation items as communication, love, respect, patient, honest, sharing, empathy, mercy and personality and all schools try to teach same values all around the country. In the implementation of value education, the value/character education teacher do not follow data driven decision making procedures and procedures of evidence based practices. In short, there is a need for and interest in implementing evidence-based and effective system-wide behavioral interventions in early childhood education.

While there is a need and an increasing interest in SWPBIS in Turkey, the research base is still limited (Erbaş, 2002; 2005; Erbaş, Kırcali-iftar, \& Tekin-iftar, 2010; Vuran, 2010). The first SWPBIS implementation took place at high and middle school levels in one private school in Istanbul between 2008 and 2013. However, no research study published on the effectiveness of the implementation (www.europbs.com). Ünlü and colleagues (2013) and Atbaşı (2016) have studied the implementations of SWPBIS at classroom level in primary schools. To our knowledge, the first study to implement SWPBIS in early childhood education was conducted by the first author of this article (Melekoğlu, 2017). We will discuss the study and its implications for future implementation efforts later in this article.

SWPBIS provides a structured yet flexible process to researchers and practitioners to design their own contextually fit implementation based on school communities' needs, goals, and resources. In U. S., there has been a policy level support and technical assistance for schools to implement SWPBIS since 1997. The Technical Assistance Center on Positive Behavioral Interventions and Supports was funded by the U.S. Department of Education, the Office of Special Education Programs (OSEP). The mission of this national center is "to define, develop, implement, and evaluate a multitiered approach to Technical Assistance that improves the capacity of states, districts and schools to establish, scale-up and sustain the PBIS framework" (PBIS.org, 2016). There are numerous web-based resources, written resources and publications for SWPBIS implementers.

In the U.S. education system, there is an autonomy for schools and school districts to make decisions about academic and behavioral programs that will use in their local contexts. On the contrary, across Turkey, school administrations and districts (i.e., Milli Egitim Mudurlukleri) have to follow the national policies. SWPBIS has not been recommended by the Turkish Ministry of National Education. This may be due to the lack of research in the literature as well as limited information among policy makers, education leaders, educators, parents, and advocacy groups regarding SWPBIS. To inform the future implementations of SWPBIS in early childhood, in what follows we present the implementation steps of SWPBIS in early childhood education based on Melekoğlu's study (2017).

\section{Implementation Steps of SWPBIS in Early Childhood Education}

Administrators and the whole school community should be have buy in SWPBIS. Therefore, the first step in the implementation of SWPBIS in Turkey is to inform school and district leadership, teachers, school staff, and parents/legal guardians about SWPBIS, its implementation procedures, benefits for students and adults with a timetable and an estimated cost and resources needed and expectations from schools, 
teachers, and parents. teachers. Researchers can prepare posters, presentations, booklets to reach out all stakeholders.

If the staff is interested, the second step is building a coalition among teachers, parents and administration. Sustaining this collation is important. This step is the most important step to imply SWPBIS because teachers may not want to involve in study due to heavy work responsibilities. In this case, researchers have to explain clearly their expectations from teachers and motivate educators. Researchers' knowledge, experiences and communication style are very important to build this step (Melekoğlu, 2017).

The third step is building SWPBIS team. Researchers may serve as team leaders who coordinate the implementation and the study. Since there is limited employee in totally in early childhood education settings, all employees have to get involve in the study if they choose to do so. It is also important to facilitate parents' involvement in the SWPBIS team. Team leaders can participate in schools' parentteacher organizations to maintain buy-in and active and sustained participation in SWPBIS.

The fourth step is establishing roles and responsibilities of the team. During implementation process, the team may assign a data manager, a communication coordinator, a financial coordinator, a technology support person, a counselor, and someone to organize activities and meetings (Stormont et al., 2008). The team determines actions, responsibilities and division of labor among SWPBIS team members.

After determining the responsibilities of the team, baseline data about the behavioral outcomes such as office discipline referrals and school climate should be collected because teachers' attitudes usually start to change with the teacher-training program even though SWPBIS intervention strategies are not applied (Stormont et. al., 2008). At this step, researchers usually collect data from teacher, students, parents and school administrators to determine the needs, strengths, and goal of the school community. Researchers generate data on the implementation process and outcomes such as implementation fidelity, school climate, and behavioral incidents based on their research questions and research design. For instance, they can make observa- tion in and around of the school environment, conduct teacher and parent interviews and observations (Melekoğlu, 2017).

The next step is to provide staff and parent training sessions. Since the SWPBIS framework and other multi-tier, prevention models are new in Turkey, professional development programs are crucial. Researchers may lead the professional development activities. Professional development sessions for teachers may be difficult because teachers have to attend to it outside of their working hours (Melekoglu, 2017). Researchers should inform teachers about teacher training process in the beginning of the implementation. The seventh step is to collect baseline data regarding behavioral outcomes and needs of students and adults in the school.

In the eighth step, the team determines behavioral expectations and three to five school values in the school environment and classrooms and select evidence-based strategies for each tier of intervention (Stormont et al., 2008). Schoolwide behavioral expectations are six to ten items that should be age appropriate. The SWPBIS team describes the mean of each expectation with positive expression and attitudes and how to assess the outcomes.

The ninth step includes preparing the materials. Since young children do not read often, all expectations should be visually displayed on the hallways, in the classroom, kitchen, and restrooms. Preparing these materials may be challenging since financial and technological support is needed (Melekoglu, 2017). The SWPBIS team can get financial, social, and academic support from the school's parent teacher organizations. They may also apply for grants. At this step, the SWPBIS team may need to do some physical change. For instance, Turkish Ministry of National Education regulation (2012) requested from school administrations to design learning centers (öğrenme merkezi) within each classroom. However, not all schools can follow this regulation because of inadequate class size, lack of material and personnel resources. According to PBIS strategies, researcher can do some physical arrangements in the schools or classrooms about what trigger off children to problem behaviors if it is necessary (Stormont et al., 2008).

At the tenth step, applications of the SWPBIS strategies are prepared (Mele- 
koğlu, 2017). The planned actions, timelines, desired outcomes (e.g., increased sense of positive social climate), changes, and decisions should be shared with all students, staff and parents (Sugai \& Horner, 2002b, 2006). Ideally, the SWPBIS implementations should be owned and led by the whole school community (Bal, 2016). The need to teach, model, and reward the behavioral expectations, observe student and adult behaviors and interactions, collect data in multiple school settings, create a positive learning environment, recognize the students who engage in desired behaviors, and follow the SWPBIS implementation plan determined the team following the SWPBIS framework. Moreover, researchers collect data for reliability and fidelity of the SWPBIS implementation. The last step is to evaluate the impact of SWPBIS implementation and collect data for the social validity of SWPBIS (Melekoğlu, 2017).

\section{Conclusion}

This article present information regarding the implementation of SWPBIS in early childhood education in Turkey. The Ministry of National Education, school districts, school leaders, teachers, support staff, and parents are in need for research-based, socially and developmentally appropriate behavioral support and intervention models to improve the behavioral outcomes of students and create safe, positive, and inclusive schools in Turkey. SWPBIS is a promising research-based approach to prevent behavioral problems and support social and academic developments of students. SWPBIS has been implemented across multiple countries and education systems struggling with behavioral problems over three decades. SWPBIS has been found effective in identifying and addressing problem behaviors in schools (Bradshaw Mitchell, O'Brennan, \& Leaf, 2010; Honer \& Sugai, 2006). This article introduces SWPBIS to education researchers, policy makers, educators, and families and provides guidelines regarding its effective and culturally responsive adaptation in Turkish education system.

\section{References}

Algozzine, B., Daunic, A. P., \& Smith, S. W. (2010). Preventing problem behaviors:
Schoolwide programs and classroom practices (Second Edition). California, CA: Corwin.

American Psychiatric Association. (2000). Diagnostic and statistical manual of mental disorders: DSM-IV-TR. Washington, DC: American Psychiatric Association.

American Psychiatric Association. (2013). Diagnostic and statistical manual of mental disorders: DSM-V-TR. Washington, DC: American Psychiatric Association.

Anderson, E. M. (2007). Managing challenging behaviors in early childhood: Effect of theoretical orientation on strategy recommendation. Unpublished doctoral dissertation. Gainesville, FL: University of Florida.

Atbaşı, Z. (2016). Sınıf içi davranışların düzenlenmesinde sınıf genelinde olumlu davranış desteği programı: Check-In/Check-Out Uygulaması. Unpublished doctoral dissertation, Ankara, Turkey: Gazi Üniversitesi.

Baer, D. M., Wolf, M. M., \& Risley, T. R. (1968). Some current dimensions of applied behavior analysis. Journal of Applied Behavior Analysis, 1(1), 91-97.

Bal, A. (2011). Culturally responsive schoolwide positive behavioral interventions and supports framework. Madison, WI: Wisconsin Department of Public Instruction.

Bal, A. (in press). Culturally responsive positive behavioral interventions and supports: A process-oriented framework for systemic transformation. Review of Education, Pedagogy, and Cultural Studies.

Bal, A. (2016). From intervention to innovation: A cultural-historical approach to the racialization of school discipline. Advance online publication. Interchange: A Quarterly Review of Education. doi: 10.1007/s10780-016-9280-z

Bal, A., Sullivan, A., \& Harper, J. (2014). A situated analysis of special education disproportionality for systemic transformation in an urban school district. Remedial and Special Education, 35(1), 3-14.

Barrett, S. ., Bradshaw C. P., \& LewisPalmer, T. (2008). Maryland statewide PBIS initiative: Systems, evaluation, 
and next steps. Journal of Positive Behavior Interventions, 10 (105), 105114.

Blackbourn, J. M., Patton, J. R., \& Trainor, A. (2004). Exceptional individuals in focus. (7th Ed.). New Jersey, NJ: Pearson Education.

Bradshaw, C. P., Mitchell, M. M., O'Brennan, L. M., \& Leaf, P. J. (2010). Multilevel exploration of factors contributing to the overrepresentation of black students in office disciplinary referrals. Journal of Educational Psychology, 102, 508-520.

Bullis, M., Walker, H. M., \& Sprague, J. R. (2001). A promise unfulfilled: social skills training with at-risk and antisocial children and youth. Exceptionality: A Special Education Journal, 9(1-2), 67-90.

Bulotsky-Shearer, R. J., Domínguez, X., Bell, E. R., Rouse, H. L., \& Fantuzzo, J. W. (2010). Relations between behavior problems in classroom social and learning situations and peer social competence in Head Start and kindergarten. Journal of Emotional and Behavioral Disorders, 18(4), 195-210.

Carr, E.G. (1997). The evolution of applied behavior analysis into positive behavior support. The Association for Persons with Severe Handicaps (JASH), 22 (4), 208-209. Retrieved from (file:///C:/Users/Egt/Downloads/The $\% 20$ Evolution $\% 20$ of $\% 20 \mathrm{Ap}$ plied\%20Behavior\%20Analysis\%20into\%20Positive-1997-Carr208-9\%20(1).pdf.

Carr, E. G., Dunlap, G.,Horner, R.H., Koegel, R. L., Turnbull, A. P., Sailor,W., \& at al. (2002). Positive behavior support: Evolution of an applied science. Journal of Positive Behavior Interventions, 4, 4-16.

Cihan, N., (2014). Okullarda değerler eğitimi ve Türkiye'deki uygulamaya bir bakiş. International Periodical For The Languages, Literature and History of Turkish, 9(2), 429-436.

Clarke, S., Worcester, J., Dunlap, G., Murray, M., \& Bradley-Klug, K. (2002). Using Multiple Measures to Evaluate Positive Behavior Support: A Case Example. Journal of Positive Behavior Interventions, 4(131), 130-145.
Dereli-İman, E. (2013). Çocuklar İçin Sosyal Problem Çözme Ölçeği' nin 6 yaş grubu için Türkiye uyarlaması ve okul öncesi davranış problemleri ile sosyal problem çözme becerileri arasındaki ilişkiler. Kuram ve Uygulamada Eğitim Bilimleri, 13(1), 479-498.

Diken, I. H., Cavkaytar, A., Batu, S., Bozkurt F., \& Kurtyılmaz, Y. (2010). First Step to Success school/home intervention program for preventing problem behaviors in young children: examining the effectiveness and social validity in Turkey. Emotional and Behavioral Difficulties, 15(3), 207-221.

Diken H. İ., \& Rutherford, B. R. (2005). First Step to Success early intervention program: A study of effectiveness with $\mathrm{Na}-$ tive-American children. Education and Treatment of Children 28(4), 444-465.

Erbaş, D. (2002). Problem davranışların azaltılmasında olumlu davranışsal destek planı hazırlama. Özel Eğitim Dergisi, 3(2) 41-50.

Erbaş, D. (2005). Baş Makale: Olumlu Davranışsal Destek. Özel Eğitim Dergisi, 6 (1) $1-18$.

Erbaş, D., Kırcaali-Iftar, G., \& Tekin-iftar, E., (2010). İşlevsel değerlendirme: Davranış sorunlarıyla başa çıkma ve uygun davranışlar kazandırma süreci (4. Baskı). Ankara: Kök Yayıncılık.

Er-Sabuncuoğlu, M., \& Diken İ. H. (2010). Early Childhood Intervention in Turkey: Current situation, challenges and suggestions. International Journal of Early Childhood Special Education, 2 (2), 149-160.

Flannery, K. B., Sugai, G., \& Anderson C. M. (2009). School-wide positive behavior support in high school. Journal of Positive Behavior Interventions, 11(3), 177-185.

Fox, L., Dunlap, G., \& Cushing, L. (2002). Early intervention, positive behavior support, and transition to school. Journal of Emotional and Behavioral Disorders, 10(3), 149-157.

Fox, L., \& Little, N. (2001). Starting early: Developing school-wide behavior support in a community preschool. Journal of Positive Behavior Interventions, 3(4), 251-254.

Horner, R. (2015, April). Linking academic and behavior supports through PBIS. Paper presented at Positive Behavioral Interventions and Supports: 
OSEP Technical Assistance Center. Retrieved from

https://www.pbis.org/school/secondary-level/user-resources

Horner, R. H., Dunlap, G., Koegel, R. L., Carr, E. G., Sailor, W., Anderson, J., Albin, R. W., \& O'Neill, R. E. (1990). Toward a technology of "non-aversive" behavioral support. Journal of the Association for Persons with Severe Handicaps, 15(3), 125-132.

Horner, R. H., Dunlap, G., Koegel, R. L., Carr, E. G., Sailor, W., Anderson, J., Albin, R. W., \& O'Neill, R. E. (2005). Toward a technology of "non-aversive" behavioral support. Research and Practice for Persons with Severe Disabilities, 30(1) 3-10.

Horner, H. R., \& Sugai, G. (2000). Schoolwide behavior support: An emerging initiative. Journal of Positive Behavior Interventions, 2(4), 231-232.

Horner, R. H., Sugai, G., Smolkowski, K., Eber, L., Nakasato, J., Todd, A. W., \& Esperanza, J. (2009). A randomized, wait-list controlled effectiveness trial assessing school-wide positive behavior support in elementary schools. Journal of Positive Behavior Interventions, 11(3), 133-144.

Individuals with Disabilities Education Improvement Act of 2004, $20 \mathrm{U}, \mathrm{S}, \mathrm{C}, \S$ 1400 et seq. (2004), Reauthorization of the Individuals with Disabilities Education Act of 1990.

Kincaid, D., Dundalp, G., Kern, L., Lane, K. L., Bambara L. M., Brown, F., Fox, L., \& Knoster T. P. (2016). Positive behavior support: A proposal for updating and refining the definition. Journal of Positive Behavior Interventions, 18(2), 69-73.

Lewis, T. J., \& Sugai, G. (1999). Effective behavior support: A systems approach to proactive schoolwide management. Focus on Exceptional Children; 31 (6), 1-24.

Lohrmann, S., \& Talerico, J. (2004). Anchor the boat: A classwide intervention to reduce problem behavior. Journal of Positive Behavior Interventions, 6(113), 113-120.

Melekoğlu, M., (2017). Exploring the effectiveness of school-wide positive behavior support model on problem behaviors and social skills in early child- hood. Unpublished doctoral dissertation, Eskişehir, Turkey: Anadolu University.

Melekoğlu, M. Diken, H. İ., Çelik, S., \& Tomris, G. (2014). Antisosyal davranışları önlemeye yönelik Başarıya Ilk Adım Erken Eğitim Programının etkililiği ile ilgili yapılan bilimsel çalışmaların incelenmesi. International Journal of Early Childhood Special Education (INT-JECSE), 6(1), 55-79.

Milli Eğitim Bakanlığı (MEB), (2012a). Özel Eğitim Hizmetleri Yönetmeliği. Haziran 12, 2014 tarihinde T.C. Milli Eğitim Bakanlığı Özel Eğitim ve Rehberlik Hizmetleri Genel Müdürlüğü: Retrieved from http://mevzuat.meb.gov.tr/html/26184_0.html.

Milli Eğitim Bakanlığı (MEB), (2012b). Okul Öncesi Eğitim Kurumları Yönetmeliği. Retrieved from http://mevzuat.meb.gov.tr/html/25486_html.

Milli Eğitim Bakanlığı (MEB), (2014a). 3648 aylık çocuklar için sosyal beceri destek eğitimi etkinlik kitabı (OSBEP). Retrieved from

http://tegm.meb.gov.tr/meb_iys_dosya lar/2014_11/14084455_3648aylkocukl arinokulncesisosyalbeceridestekeitimietkinlikkitab.pdf.

Milli Eğitim Bakanlığı (MEB), (2014a). Early Childhood and Primary Education Institutions Regulation. Retrieved from http://www.resmigazete.gov.tr/eskiler/ 2014/07/20140726-4.htm.

Moll, L. C., Amanti, C., Neff, D., \& Gonzàles, N. (1992). Funds of knowledge for teaching. Theory into Practice, 31, 132-141.

Safran, S. P., \& Oswald, K. (2003). Positive behavior supports: Can schools reshape disciplinary practices? Council for Exceptional Children. 69(3), 361373.

Sprague, J., \& Perkins, K. (2009). Direct and collateral effects of the First Step to Success program. Journal of Positive Behavior Interventions, 11(4), 208221.

Steed, E. A., \& Webb, M. L. (2012). The Psychometric Properties of the Preschool-Wide Evaluation Tool (PreSET). Journal of Positive Behavior Interventions, 15(4), 231-241.

Stormont, M., Lewis, J. T., \& Beckner, R. (2005). Positive Behavior Support Sys- 
tems: Applying Key Features in Preschool Settings. Teaching Exceptional Children, 37(6), 42-49.

Stormont, M., Lewis, J. T., Beckner, R., \& Johnson, W. N. (2008). Implementing positive behavior support systems in early childhood and elementary settings. California, CA: Corwin Press.

Sucuoğlu B., \& Bakkaloğlu, H. (2013). Okul öncesi eğitimde kaynaştırma: Ne, ne zaman, nerede, neden, nasıl, kim. Ankara, Turkey: Kök Yayıncılık.

Sugai, G., \& Horner, R. (2002a). The Evolution of Discipline Practices: SchoolWide Positive Behavior Supports. Behavior Psychology in the Schools, 24(1/2), 23-50.

Sugai, G., \& Horner, R. (2002b). Introduction to the special series on positive behavior support in schools. Journal of Emotional and Behavioral Disorders, 10(3), 130-135.

Sugai, G., \& Horner, R. (2006). A promising approach for expanding and sustaining the implementation of school-wide positive behavior support. School Psychology Review, 35, 245-259.

Sugai, G., Horner, R., Dunlap, G., Hieneman, M., Lewis, T.J., Nelson, C.M., Scott, T., Liaupsin, C., Sailor, W., Turnbull, A.P., Turnbull, H., Wikham, D., Wilcox, B., \& Ruef, M. (2000). Applying positive behavior supports and functional behavioral assessment in schools. Journal of Positive Behavior Interventions, 2, 131-143.

Sugai, G., \& Simonsen, B. (2012). Positive behavioral interventions and supports: history, defining features, and misconceptions. University of Connecticut. Retrieved from http://challengingbehavior.fmhi.usf.edu/explore/webinars/8.24.2012 tacsei_webinar/PBIS_revisited_June19r_2012.pdf

Sugai, G., O'Keeffe, B., \& Fallon, L. (2012). A contextual consideration of culture and school-wide positive behavior support. Journal of Positive Behavior Interventions, 14, 197-208.

Tohum Türkiye Otizm Erken Tanı ve Eğitim Vakfı (2011).

Kaynaştırma/bütünleştirmenin etkililiğini artırmak için politika ve uygulama önerileri projesi:

Kaynaştırma/Bütünleştirme Yoluyla Eğitim Destek Modeli kılavuzu.
United Nations Children Fund (UNICEF) (2001). The state of the world's children 2001: Early childhood report. Retrieved from http://www.unicef.org/sowc01/pdf/fullsowc.pdf

United Nations Educational, Scientific and Cultural Organization (UNESCO), (2005). UNESCO and sustainable development report. Retrieved from http://unesdoc.unesco.org/images/0013/001393/139369e.pdf

Ünlü, E., Vuran, S., Akdoğan, E.F., Güven,D., Yönter,S., \& Çaltık, E. S. (2013). Class-wide Positive Behavior Support Plan on Adhering to the Classroom Rules. Elementary Education Online, 12(4), 912-925.

Vuran, S. (2010). Davranış problemleri ile baş etme. In Diken, H. İ. (Ed.) İlköğretimde kaynaştırma (p. 260-287). Ankara, Turkey: Pegem Akademi.Walker, H. M., Horner, R. H., Sugai, G., Bullis, M., R. Sprague, J. R., Bricker, D., \& Kaufman, M. J. (1996). Integrated approaches to preventing antisocial behavior patterns among school-age children and youth. Journal of Emotional and Behavioral Disorders, 4(4), 194-209.

Walker, H. M., Kavanagh, K., Stiller, B., Golly, A., Severson, H. H., \& Feil, E. G. (1998). First step to success: An early intervention approach for preventing school antisocial behavior. Journal of Emotional and Behavioral Disorders, $6(2), 66-80$. 